\title{
Narrativa e escrita da história: sobre a não castidade do historiador
}

\author{
Narrative and writing of history: \\ non chastity of the historian
}

\author{
Antonio Paulo Benatte* \\ César Leonardo Van Kan Saad** \\ “... a narrativa está aí, como a vida.”
}

RESUMO

Roland Barthes, Introdução à analise estrutural da narrativa

O artigo objetiva debater teoricamente a questão da narrativa histórica, problematizando a noção de verdade segundo o paradigma científico clássico e dialogando com os desafios lançados pelos "narrativistas", que ressaltam a subjetividade inerente à tessitura textual e as fronteiras do discurso histórico com a ficção.

Palavras-Chave: Narrative. Ficção. Historiografia.

\section{ABSTRACT}

The article aims to theoretically discuss the issue of historical narrative, questioning the notion of truth as the classic scientific paradigm and dialoguing with the challenges posed by the "narrativist" which underscore the inherent subjectivity to the textual texture and borders the historical discourse with fiction.

Keywords: Narrative. Fiction. Historiography.

\footnotetext{
* Doutor em história. Professor da Universidade Estadual de Ponta Grossa -UEPG. Pesquisador-colaborador do IFCH-UNICAMP.

** Mestrando em História pela Universidade Federal do Rio Grande do Sul - UFRGS.
} 
Há quase dois mil e quinhentos anos o historiador faz a história porque a escreve. A pesquisa é inseparável da escrita: o que o historiador faz é historiografia. O conhecimento histórico é um constructo cultural narrativo que revigora a relação entre presente, passado e futuro, de modo a compor sentidos singulares dotados de historicidade própria. A narrativa de um historiador é enredada a sentidos coletivos, sociais, atribuídos a uma consciência histórica e historiadora. Na longa duração, é possível diferenciar mentalidades ou culturas históricas articuladas a conteúdos e cânones historiográficos datados e contingentes. Toda proposição de um passado pelo discurso histórico é uma produção de sentido, seja um sentido ordenador de todo um corpo social, ou o produto de uma forma singular de narrar acontecimentos. Ambos os sentidos compõem o próprio sentido (do tempo, da história, do mundo, da vida); separá-los é um recurso didático que evidencia as propriedades da narrativa no discurso.

É de suspeitar que ainda hoje não se tenha reconhecido os domínios discursivo, narrativo e escriturístico constitutivos do conhecimento histórico enquanto produção de sentido. Estudar a história, diz Keith Jenkins, "refere-se a como ler e entender o passado e o presente"; por isso "parece importante usar discursos que tenham por grandes preocupações as 'leituras' e a elaboração de significados." (JENKINS, 2001, p. 20) Não se deveria, pois, aceitar que existe "A História" como uma significação universal e coesa, totalidade estruturada ou substância dada a priori. De início, o plural é plausível; existem multiplicidades de histórias possíveis, compósitos discursivos materializados em inumeráveis narrativas. Um passado narrativizado é proposto pelo historiador a diferentes comunidades interpretativas de leitores virtuais; essas comunidades desempenham um papel ativo na produção do sentido histórico mediante a recepção e apropriação dos textos.

Construtos linguísticos e intertextuais, história e historiografia são por vezes considerados sinônimos. Essa sinonímia naturaliza as concepções de passado, confunde práticas e representações e assume formas ideológicas diversas na escrita da história. Como reitera Jenkins, história e passado são "coisas" diferentes, livres uma da outra, pois um mesmo objeto de investigação "pode ser interpretado diferentemente por diferentes práticas discursivas, ao mesmo tempo em que, em cada uma dessas práticas, há diferentes leituras interpretativas no tempo e no espaço." (JENKINS, 2001, p. 24) Essas formas possíveis de passado, ou de interpretações que se lhe atribuem, são elaboradas pelo historiador-narrador situado em uma cultura histórica. A prática de escrever o passado é, ademais, atrelada a instituições sociais que regulam o saber e suas repercussões. Esses sujeitos de conhecimento, ainda conforme Jenkins, "trabalham sob todo tipo de pressuposto e pressão, coisas que, é claro, não atuam sobre as pessoas do passado." (JENKINS, 2001, p. 30) Por isso 
mesmo, o historiador não deveria apagar-se em seu texto, como a dissimular um ponto de vista.

[...] ainda vemos historiadores tentarem invocar ante nossos olhos o espectro do passado real, um passado objetivo sobre o qual os relatos desses historiadores seriam precisos e até verdadeiros, na acepção mais ampla da palavra. Pois bem: acho que tais pretensões à verdade não são - e nunca foram - passíveis de realizar-se, e eu diria que em nossa atual situação isso já deveria ser óbvio [...]. (JENKINS, 2001, p. 30)

Se existe história porque há um texto (vários textos), é preciso interrogar o estatuto desse texto enquanto semióforo dado a ler a um público mais ou menos amplo e heterogêneo. As questões são assim deslocadas: o que faz o historiador quando escreve a história? O que significa escrevê-la? Qual é o modo de produção do texto? Quais os efeitos de sentido produzido pelo encontro do mundo do texto com o mundo do leitor? Para responder a esse questionário, a discussão sobre a narrativa é importante, seja do ponto de vista teórico, metodológico ou estético, sem falar nas pesquisas em história da historiografia. Se a condição de possibilidade do conhecimento histórico é a narrativização do próprio mundo histórico, essa reflexão é necessária, inclusive, para alimentar a prática do historiador.

A inteligibilidade da história depende da escritura, indissociável da leitura. No texto narrativo escrito em prosa convergem as convenções culturais e as operações técnicas que tornam o discurso histórico possível. Como afirma Paul Ricoeur, "a história é uma escrita, de uma ponta a outra: dos arquivos aos textos de historiadores, escritos, publicados, dados a ler." (RICOEUR, 2007, p. 247) A incontornável relação dos historiadores com o escrito dá-se em mais de um sentido, desde a heurística das fontes até o modo como o discurso histórico, publicado e dado a ler sob a forma de um texto escrito, configura e refigura culturalmente um passado por definição extinto.

A narrativa demarca claramente o problema da ligação entre os conteúdos da história grafus de uma prática - e as suas formas ou modalidades expressivas e comunicacionais. A história, nesse ponto, tangencia as narrativas ficcionais. Evidenciar a dimensão ficcional da história não implica negar o seu estatuto de conhecimento, mas tornar ainda mais complexa as operações que o possibilitam. A diluição das fronteiras entre os discursos histórico e literário não estabelece uma perfeita equação entre historiografia e ficção. Mesmo em Hayden White, talvez o mais radical dos historiadores preocupados com a narrativa, "a teoria tropológica não destrói a diferença entre fato e ficção, mas redefine as relações entre os dois dentro de qualquer discurso." (WHITE, 1994b, p. 37)

Além disso, a separação entre gêneros literários e historiográficos não é assim tão simples. Toda história é, em maior ou menor grau, figurativa e ficcional; em contrapartida, a literatura não é destituída da representação de conteúdos históricos realmente existentes. 
Muitos dos termos podem ser intercambiáveis e observam-se gêneros compósitos, híbridos textuais, a exemplo do romance histórico ${ }^{1}$ e da epopeia. Toynbee dizia que quem lê a Ilíada como história logo descobre que ela está cheia de ficção; mas, do mesmo modo, quem a lê como ficção logo descobre que ela está repleta de história. ${ }^{2}$ Walter Benjamin reconhecia na literatura uma espécie de "historiografia inconsciente" de uma época; de certo modo, poderse-ia inverter a proposição e afirmar que a historiografia não deixa de ser, ela própria, uma espécie de "literatura inconsciente" de uma época. ${ }^{3}$

Seja como for, há um recente esbatimento das fronteiras entre a história e a ficção. Como diz o crítico literário Manoel Frias Martins, a teoria literária, em especial a narratologia, assim como o romance pós-moderno, tem reconhecido "a existência de uma figura ficcional no discurso do historiador (mesmo no mais convicto partidário da história literal)"; acrescenta que "essa figura resulta exatamente da importância que a mediação da linguagem adquire na construção do discurso do historiador e, consequentemente, do esforço retórico que lhe está subjacente." (MARTINS, 1992, p. 14) Martins sintetiza as teses "narrativistas" na seguinte passagem:

O historiador (qualquer historiador) pode acreditar que o seu trabalho se orienta para a demonstração da verdade do passado. Porém, só quando os eventos são postos numa estrutura narrativa é que essa verdade pode ser exibida. Ora, a narrativa ou a forma narrativa não é uma propriedade dos eventos, mas sim o processo a que o historiador tem obrigatoriamente de recorrer para compreender (reconstruir) os eventos. Se assim é, então ler um ensaio histórico equivale a confrontarmo-nos com estratégias de uma subjetividade narrativa que necessariamente nos impede de saber onde acaba o factual e começa o

\footnotetext{
1 "Na realidade, o romance, como toda obra literária, mantém relações complexas com a história, quer se trate da história factual, ou de relato dos acontecimentos. [...] o século XIX assistiu ao nascimento e à codificação de uma forma romanesca em que a história (relato) se mistura com a ficção. Trata-se, é claro, do romance histórico, cujo iniciador permanece Walter Scott (1771-1832)." (GOULEMOT, 1993, p. 694).

2 "A história, como o drama e como o romance, é filha da mitologia. É uma forma particular de compreensão e de expressão, onde - como nos contos de fadas de que as crianças tanto gostam, e nos sonhos próprios de adultos 'sofisticados' - não foi traçada a linha de demarcação entre o real e o imaginário. Disse-se, por exemplo, da Ilíada, que quem a lê como narrativa histórica lá encontra a ficção, e que, pelo contrário, quem a lê como lenda lá depara com a história. A esse respeito, todos os livros de história se assemelham à Ilíada, pois não podem eliminar completamente a ficção. O simples fato de escolher, de arranjar e representar os fatos constitui uma técnica que pertence ao domínio da ficção." (TOYNBEE, 1972, p. 11).

${ }^{3}$ Sobre a concepção benjaminiana, escreve Flávio Kothe: "As obras literárias, mesmo não pretendendo ser e não sendo um mero registro histórico, acabam sendo também uma historiografia inoficial. Na medida mesma em que não querem ser documento, seu caráter autônomo lhes permite uma liberdade de registro e transmissão que escapa à historiografia oficial, comprometida com as omissões, cortes e deformações que as relações de produção lhe impõem." (KOTHE, 1976, p. 79).
} 
criativo. Não é esse o princípio que orienta a representação literária, bem como a percepção cognitiva que dela temos como ficcionalidade? (MARTINS, 1992, p. 14)

Depois de mais de um século sob o domínio de uma frágil e sempre postergada ideia de cientificidade, os limites entre a história e a literatura tornaram-se evanescentes; é forçoso reconhecer que "o caráter de ciência, conquistado [mas até que ponto?] pelo conhecimento histórico, não suprime a base narrativa, que mantém o seu nexo com o ficcional." (NUNES, 1988, p. 12). Com a crise dos grandes modelos explicativos das ciências humanas, a narrativa - a prática escriturística, grafológica e grafrocrata da história - voltou a ser um problema na ordem do dia. Em linhas gerais, as implicações ao mesmo tempo literárias e filosóficas das teses "narrativistas" representam um ataque contundente aos preceitos e preconceitos de uma noção de história-ciência herdada do século XIX. Os metodólogos da história, com o seu ideal científico de estrita objetividade, fizeram tabula rasa do papel da linguagem escrita e da retórica no trabalho do historiador. $O$ historiador acadêmico em geral seguiu pelo mesmo caminho. Mas note-se, de passagem, que o fato de "negarem" ou obliterarem a narrativa não fez dos historiadores modernos maus escritores da história. Afinal, Ranke, Febvre, Braudel ou mesmo E. P. Thompson, entre muitos outros, permanecem clássicos da historiografia justamente pela qualidade estética e retórica dos textos que escreveram, independentemente da "superação" ou crise de paradigmas ou modelos explicativos. Sobre a "natureza essencialmente literária dos clássicos históricos", escreve White: "Há algo numa obra prima da história que não se pode negar, e esse elemento não negável é a sua forma, a forma que é a sua ficção." E mais adiante: "E é precisamente pelo fato de os grandes clássicos da história [...] não poderem ser definitivamente invalidados que devemos atentar para os aspectos especificamente literários da sua obra como sendo elementos decisivos, e não apenas subsidiários, da sua técnica historiográfica." (WHITE, 1994a, p. 106,114).

A recusa e o eclipse da narrativa são eles mesmos argumentos retóricos em prol de uma história científica ou, como dizia Lucien Febvre, "cientificamente conduzida". (FEBVRE, 1977, p. 43) Como explica White,

Tocqueville, Burckhardt, Huizinga y Braudel, por citar sólo a los maestros más señalados de la historiografía moderna, rechazaron la narrativa en algunas de sus obras historiográficas, presumiblemente a partir de la suposición de que el significado de los acontecimientos que deseaban relatar no era susceptible de representación en modo narrativo. Se negaron a contar una historia del pasado o, más bien, no contaron una historia con etapas inicial, intermedia y final bien delimitadas; no impusieron a los procesos que les interesaban la forma que normalmente asociamos a la narración histórica. Si bien es cierto que narraban la realidad que percibían, o que pensaban que percibían, como existente en o detrás de la evidencia que habían examinado, no narrativizaban esa realidad, no le imponían la forma de un relato. Y su ejemplo nos permite distinguir entre un discurso histórico que narra y un discurso que narrativiza, entre un discurso que adopta abiertamente 
una perspectiva que mira al mundo y lo relata y un discurso que finge hacer hablar al propio mundo y hablar como relato. (WHITE, 1992, p. 18).

Ou seja, embora vinculados a matrizes disciplinares que sancionam o sentido moderno da história por seu discurso científico, os grandes historiadores modernos não deixaram de narrativizar o passado conferindo-lhes sentidos possíveis, expostos e dados a ler em diferentes linhagens e tradições historiográficas. Simplesmente, os acontecimentos não significam a si mesmos. É a prática de escritura/leitura ${ }^{4}$ que imputa sentido a um conjunto de acontecimentos, transformando-os em fatos, processos ou estruturas. Em seu ensaio $O$ efeito de real, Roland Barthes cita a crítica de Nietzsche ao positivismo: "Não existe fato em si. É sempre preciso começar por introduzir um sentido para que haja um fato." (BARTHES, 2004b, p. 155) Compreende-se assim a ironia de Barthes em relação ao paradoxo do discurso histórico moderno:

[...] o fato nunca tem mais do que uma existência linguística (como termo de um discurso), e, no entanto, tudo se passa como se essa existência não fosse senão a "cópia" pura e simples de uma outra existência, situada num campo extratextual, o "real”. (BARTHES, 2004b, p. 155).

Para Barthes, a ilusão referencial de todo discurso de pretensão realista ou objetiva jaz na confusão do referente com o significado: "na história 'objetiva', o 'real' nunca é mais do que um significado não formulado, abrigado atrás da onipotência aparente do referente. Essa situação define o que se poderia chamar de efeito de real.” (BARTHES, 2004b, p. 156).

A partir da desmistificação barthesiana do realismo como efeito linguístico próprio da historiografia moderna, White sustenta que o discurso histórico é uma elaboração psicológica e ideológica; ou, mais precisamente, uma elaboração da "imaginação" (WHITE, 2011, p. 457), ato "performativo por natureza, através do qual aquele que profere o discurso (uma entidade puramente linguística) preenche o lugar do objeto do proferido (uma entidade psicológica ou ideológica)." (WHITE, 2011, p. 457) Nas palavras (difíceis) de Barthes, os discursos históricos supõem uma dupla operação:

Num primeiro momento (essa decomposição não é, evidentemente, mais que metafórica), o referente é destacado do discurso, fica-lhe exterior, fundador, é considerado como seu regulador: é o tempo das res gestae, e o discurso se dá simplesmente como historia rerum gestarum;

\footnotetext{
4 Escritura aqui entendida como a forma escritural, ou mesmo gráfica, de um discurso. Mas tal reconhecimento requer outros mais, pois entender a escritura como texto é ter claro que "[...] um texto não é feito de uma linha de palavras a produzir um sentido único, de certa maneira teológico (que seria a "mensagem" do Autor-Deus), mas um espaço de dimensões múltiplas, onde se casam e se contestam escrituras variadas, das quais nenhuma é original: o texto é um tecido de citações, oriundas dos mil focos da cultura." (BARTHES, 2004a, p. 62).
} 
mas, num segundo momento, é o próprio significado que é rechaçado, confundido no referente; e o referente entra em relação direta com o significante e o discurso, encarregado apenas de exprimir o real, acredita fazer economia do termo fundamental das estruturas imaginárias, que é significado. Como todo discurso de pretensão "realista" o da história acredita fornecer apenas um esquema semântico de dois termos, o referente e o significante; a confusão (ilusória) do referente com o significado define, como se sabe, os discursos suireferenciais, como o discurso performativo; pode-se dizer que o discurso histórico é um discurso performativo com trucagem, em que o constativo (o descritivo) aparente não é de fato mais do que o significante do ato de palavra como ato de autoridade. (BARTHES, 2004b, p. 178).

O sentido (ou o significado) é produto do ato performativo de uma imaginação mais ou menos documentada que grafa uma intriga ou uma trama possível; essa operação apela para formas constitutivas de passado, formas inscritas na cultura, operando assim uma "emolduração" do próprio tempo na narrativa. Segundo White, a trama de uma narração impõe-se a um significado, os acontecimentos que determinam seu nível de história, para então revelar, ao final, uma estrutura que seria, por assim dizer, "imanente" aos acontecimentos. (WHITE, 1992, p. 35)

A produção de sentido, como vimos, acontece também no processo de recepção do texto por diferentes comunidades interpretativas. Da perspectiva do escritor, um texto histórico atribui um determinado sentido aos restos do passado inscritos no presente; mas, para o leitor, um texto é indefinidamente aberto a novas significações, tanto realmente no presente quanto virtualmente no futuro. $\mathrm{O}$ extinto não pode ser experimentado, somente imaginado mediante a narrativização dos documentos e suas diferentes interpretações. White afirma que "esta es la razón por la que la trama de una narrativa histórica es siempre confusa y tiene que presentarse como algo que 'se encuentra' em los acontecimientos en vez de plasmado en ellos mediante técnicas narrativas.” (WHITE, 1992, p. 35) A própria disposição acontecimental, ou mesmo a formalização de fatos e eventos, é, por si só, o reconhecimento de uma primeira narrativização do "real". White aprofunda essa análise em um ensaio, $A$ questão da narrativa na teoria da histórica contemporânea. Em sintonia com Barthes, critica a ideia de narrativa como tendo uma função meramente comunicativa na produção do conhecimento histórico. Esta última tradição entende que o modo legítimo da representação histórica seria o da explanação, concebida como "mensagem sobre um referente (o passado, eventos históricos, etc.) e seu conteúdo, a um só tempo, 'informação' (os fatos) e 'explanação' (o relato narrativo)." (WHITE, 2011, p. 462-63) Os fatos, em sua particularidade, e os relatos em sua generalidade, encontrariam uma correspondência no real; o critério é o valor de verdade, fundado em uma operação metódica mais que no critério de coerência invocado por discursos poéticos ou retóricos. (WHITE, 2011, p. 463) Para os teóricos que defendem o caráter comunicativo do discurso narrativo histórico, "a correspondência da 'história' com os eventos que relata é estabelecida no nível do conteúdo conceitual da mensagem”. 
(WHITE, 2011, p. 463) Estes podem ser pensados como conjuntos seriais de eventos ligados por causa e efeito, por correspondência, ou ainda por "razões" ou intenções dos agentes históricos. Como analisa White,

[...] a forma narrativa do discurso é somente um meio para a mensagem, e não tem mais valor de verdade ou conteúdo informacional do que qualquer outra estrutura formal, como o silogismo lógico, a figura metafórica, ou a equação matemática. Considerada como código, a narrativa é um veículo como o código Morse, que serve para a transmissão de mensagem pelo aparato telegráfico. O que significa, dentre tantas coisas, que, assim encarado, o código narrativo não acrescenta nada à informação ou ao conhecimento que não possa ser organizado por outro sistema de codificação discursiva. (WHITE, 2011, p. 464).

Esses modos disciplinares da historiografia concebem a narrativa como um simples ornamento, apêndice ou acabamento da operação historiográfica; o texto seria tão somente a exposição lógica dos resultados da pesquisa, um equivalente do relatório científico. É significativo que, nessa tradição, as próprias reflexões sobre o estatuto da narrativa foram tímidas e marginais. Para White, este modo de conceber a narrativa é falho, pois não leva em conta o grande número de formas narrativas que toda cultura coloca à disposição dos leitores, entre eles o historiador. Em suma, o que uma tradição considera apenas uma operação secundária, outra, aqui defendida por White, considera uma forma de discurso usada para apresentar eventos, sejam eles históricos ou não. O que distinguiria os enredos históricos dos ficcionais seria, antes de tudo, o conteúdo, e não a forma.

O estreitamento entre história e literatura faz ver que o discurso narrativo não é um código monolítico, mas um artefato múltiplo, complexo, rico em sugestão e variedade de efeitos. Isso implica reconhecer o historiador como artista, inventor e criador, e não um consumidor passivo de códigos culturais. Nesse sentido, a crítica às teses objetivistas e comunicacionais repercute ainda mais diante da prerrogativa barthesiana de tomar o discurso histórico em suas dimensões performativa e pragmática:

\footnotetext{
Da perspectiva propiciada por este modelo, um discurso é visto como um aparato para a produção de sentido, mais do que apenas como um veículo para a transmissão de informação sobre um referente extrínseco. Assim tomado, o conteúdo do discurso consiste tanto em sua forma como em qualquer informação que possa ser extraída de sua leitura. Segue-se que mudar a forma do discurso pode não ser mudar a informação sobre seu referente explícito, mas certamente mudar o significado produzido por ele. (WHITE, 2011, p. 465).
}

A produção de sentido ou significado pela narração historiadora implica que nenhum tipo de conjunto ou sequência de eventos reais é intrinsecamente dotado de uma 
identificação adjetiva ou substantiva: não são trágicos, cômicos ou farsescos por natureza; assumem uma forma ou outra mediante a imposição de uma urdidura de enredo ou um processo de enredamento que "acione" tal ou qual figuração inscrita historicamente na cultura. O historiador nada cria ex nihil. Se há alguma lógica anterior à transfiguração dos eventos em narrativa, essa é da ordem da tropologia. ${ }^{5} \mathrm{Em}$ suma, na historiografia, forma e conteúdo encontram-se intrinsecamente conectados; desconsiderar essa articulação é um modo inadequado de analisar tais operações.

Com o reconhecimento de que o discurso da história é inseparável da performance narrativa, o historiador assume uma posição mais subjetiva ou menos recalcada, enquanto que o discurso da história como ciência pressupunha, de certa forma, a representação da ausência do autor, no sentido de não interferir naquilo que supostamente seria "mostrado" pela análise crítica dos documentos. Cada vez mais as reflexões sobre a textualidade narrativa do discurso histórico tem enfatizado o caráter poiético em detrimento do caráter mimético da historiografia. A representação do passado não é mimesis (cópia, imitação ou duplo do real), mas poiesis, criação linguística do real mediante as diferentes estratégias retóricas e os variados artifícios de narrativização do passado e da própria temporalidade. Barthes, em Introdução à análise estrutural da narrativa, traz uma passagem longa, mas esclarecedora:

[...] a função da narrativa não é de "representar", é de constituir um espetáculo que permanece ainda para nós muito enigmático, mas que não saberia ser de ordem mimética; a "realidade" de uma sequência não está na continuação "natural" das ações que a compõe, mas na lógica que se aí expõe, que aí se arrisca e que satisfaz; poder-se-ia dizer de uma outra maneira que a origem de uma sequência não é a observação da realidade, mas a necessidade de variar e de ultrapassar a primeira forma que se ofereceu ao homem, a saber a repetição; uma sequência é essencialmente um todo no seio do qual nada se repete; a lógica tem aqui um valor emancipador - e toda narrativa com ela; é possível que os homens reinjetem sem cessar na narrativa o que conhecem, o que viveram; ao menos isto está em uma forma que, ela, triunfou da repetição e instituiu o modelo de um vir a ser. A narrativa não faz ver, não imita; a paixão que nos pode inflamar à leitura de um romance [ou no caso, uma narrativa historiográfica] não é a de uma "visão" (de fato, não "vemos" nada), é a da significação, isto é, de uma ordem superior da relação, que possui, ela também, suas emoções, suas esperanças, suas ameaças, seus triunfos: "o que se passa" na narrativa não é do ponto de vista referencial (real), ao pé da letra: nada; "o que acontece" é a linguagem tão-somente, a aventura da linguagem, cuja vinda não deixa de ser festejada. (BARTHES, 1976, p. 60)

Além do estruturalismo e do pós-estruturalismo, essa mesma noção de poiesis do discurso histórico é enfatizada pela tradição hermenêutica. Tome-se, por exemplo, a noção

\footnotetext{
${ }^{5}$ Sobre a tropologia, cf. a introdução de White (1995). Ver também os três primeiros estudos de Ricoeur (2000).
} 
de intriga em Ricoeur (antes empregada por Veyne em uma perspectiva bastante diferente). Para o filósofo, a narrativa histórica opera e funciona como uma armação de intriga; armar uma intriga,

[...] além de ser uma síntese do heterogêneo - pois a associação dos fatos numa história contada extrai de acontecimentos esparsos um relato unificado -, ao mesmo tempo também associa intenções, causas e acasos, e finalmente extrai uma configuração temporal de uma sucessão de acontecimentos descontínuos. (RICOEUR, 2011, p. 32)

A noção hermenêutica de configuração ou refiguração da temporalidade questiona a noção de discurso mimético tanto na história como na ficção:

\begin{abstract}
A história reconstrói o passado como a ficção reinventa o mundo. Tanto uma como a outra, por um jogo de referências cruzadas (ora mais "reais", ora mais "fictícias"), contribuem juntamente a refigurar a temporalidade, no seio da qual se desenvolve a ação dos homens. (AMHERDT, 2006, p. 35).
\end{abstract}

Um dos resultados dessas análises é um enfraquecimento do realismo e da objetividade tanto na ciência quanto na literatura. Ora, sabe-se que o ideal de representação objetivista na historiografia científica foi grandemente tributário da estética realista na literatura do século XIX e XX. O realismo está para a literatura como o ideal de objetividade para a ciência, e novamente esses termos são aqui intercambiáveis. $O$ romance realista baseava-se numa estética de imitação do real. A estética realista, com seu ideal de "espelhar a realidade", casava-se perfeitamente com a epistemologia positivista e historicista e seu ideal científico de "mostrar o que realmente aconteceu", conforme a célebre expressão de Ranke.

No campo literário, a convenção realista - "com sua fé de sapateiro numa realidade objetiva que seria singelamente captada na linguagem por um sujeito-narrador atento e forte, em franca afinidade com as coisas" (SANTOS, 1995, p. 59) - foi profundamente abalada pela literatura pós-moderna de ficção. A ficção pós-moderna radicalizou a crítica modernista da linguagem, fazendo-a voltar-se contra si própria; a metalinguagem literária reflete criticamente sobre as próprias convenções de veracidade da literatura, sua "ilusão verossímil" e suas estratégicas retóricas. Trata-se de um texto "que expõe sua fraude e renega o ilusionismo" (SANTOS, 1995, p. 62), que reconhece a opacidade do mundo à interpretação e, portanto, a incerteza a que está voltada toda e qualquer prática significante. No campo científico, as críticas pós-modernas indiciam mutações epistemológicas importantes, que afetam não apenas a história em particular, mas as ciências humanas e sociais em geral. Como sintetiza o filósofo Gianni Vattimo, 
Se, na generalidade, é de fato verdade que as ciências, na sua forma moderna de ciências experimentais e "técnicas" (manipuladoras dos dados naturais), constituem mais o seu objeto do que exploram um "real" já constituído e ordenado, isto é válido de maneira muito especial para as ciências humanas. (VATTIMO, 1991, p. 21).

Ao refletir sobre a cultura e a linguagem, parte dos historiadores atentam para o fato de que o passado não é um dado que se descobre, mas um constructo linguístico, discursivo e cultural dotado ele próprio de uma historicidade singular. As noções de cultura e linguagem contribuíram para desconstruir a oposição moderna entre dois campos considerados irredutíveis: a ciência e a arte. Nesse sentido, White parte das recentes descobertas na filosofia da ciência e na filosofia da linguagem, na estética e na psicologia sobre o caráter construtivista das afirmações artísticas e científicas. A meta-história entende que o discurso histórico "constrói seu assunto no próprio processo de falar [e escrever] sobre ele". (WHITE, 1994b, p. 26) Ao contrário do que comumente se afirma, Hayden White não nega os elementos de cientificidade da história. Para ele, o caráter "ficcional", imaginário ou imaginativo da historiografia não está na invenção de acontecimentos - digamos, em falsear os dados da res gestae -, mas na configuração desses acontecimentos em estruturas narrativas de determinados tipos, mediante as quais o discurso histórico obtém um efeito de desestranhamento, conferindo assim inteligibilidade ao passado. A história não é uma pura fiç̧ão; mas comporta elementos ficcionais à medida que configura e reconfigura narrativas numa estrutura de enredo familiar aos leitores de uma determinada cultura. É nesse nível ou plano que funciona a imaginação histórica. Daí porque, segundo White, o saber histórico está mais próximo do artefato literário que das ciências "duras" (nomotético-dedutivas). A configuração dos "vestígios textualizados do passado" (ou seja, das informações documentais) em tipos específicos de estórias é o que ele chama de "urdidura de enredo". Urdir um enredo a partir de vestígios incompletos e "estranhos" é elaborar uma trama, uma narrativa a partir dos modelos de estórias que fazem parte da cultura e da sociedade do historiador e daqueles para quem o historiador escreve; trata-se de um compartilhamento de significados linguístico-culturais sem os quais seria impossível o processo de dotação de sentido ao passado.

Em suma, os acontecimentos são transformados em fatos, processos ou estruturas mediante um trabalho discursivo e textual, no qual as convenções de veracidade da narrativa são imprescindíveis. Embora não negue a parte científica da história, White não faz nenhuma concessão ao cientificismo espelhado nas ciências "duras": "Só uma inteligência tirânica e voluntariosa poderia acreditar que o único tipo de conhecimento a que podemos aspirar é aquele representado pelas ciências físicas." (WHITE, 1994b, p. 38). Ao questionar a artificialidade das fronteiras entre história e literatura, ciência e arte, razão e imaginação, aproxima a história mais da literatura que da ciência, embora afirme que ambas obtém suas forças a partir da verossimilhança, mais do que a partir de qualquer verdade objetiva. A ideia de verdade objetiva, própria da ciência do século XIX e parte do XX, 
ignorou, como vimos, o aspecto retórico do discurso escrito, as suas estratégias de persuasão e convencimento. $\mathrm{O}$ reconhecimento de que todo discurso, inclusive o mais científico, antes produz um efeito verossímil do que demonstra uma verdade objetiva é inseparável de uma redescoberta da retórica na crítica cultural pós-moderna. Segundo o filósofo Luciano Zajdsznajder,

\begin{abstract}
A modernidade não reconheceu a presença do retórico nas interações humanas. Ao afirmar a natureza específica da argumentação científica, que não buscaria persuadir mas demonstrar, ignorou o seu próprio caráter retórico. A retórica viveu anos de obscuridade, até ser redescoberta de forma prática na propaganda comercial e política. Em pouco tempo, percebeu-se a sua manifestação generalizada. Mesmo em áreas que pareciam domínio da argumentação demonstrativa, é possível apontar as intenções persuasivas. A retórica foi mais claramente entendida como a presença generalizada de relações de poder em todos os tipos de interações. (ZAJDSZNAJDER, 1994, p. 5).
\end{abstract}

Assim, a própria ideia de objetividade é questionada. O texto objetivo, para Barthes, não é mais que a supressão, no discurso, dos signos do sujeito, ao mesmo tempo em que se constrói, também no e pelo discurso, a figura de um sujeito objetivo implícito. As concepções pós-estruturalistas tendem a pensar que o discurso histórico não copia, espelha ou reproduz a realidade - não é mimético -, mas, pelo contrário, produz um efeito poiético. Se o real é tão imaginado quanto o imaginário, as representações do real constituem o real no ato mesmo de apresentá-lo. O real não produz narrativas; as narrativas produzem o real, a começar pela realidade do tempo e de seu escoamento. $O$ discurso histórico não nos revela a verdade sobre o passado, mas funda-se ele próprio em uma "convenção de veracidade" que, ao mesmo tempo, o legitima e o diferencia de outros tipos de discurso, especialmente do imaginativo fundado em outro tipo de convenção cultural - a "convenção de ficcionalidade". (MIGNOLO, 1993, p. 122) E tanto o efeito de real quanto a convenção de veracidade obrigam o historiador a reconhecer os elementos especificamente literários e retóricos de seu discurso textualizado. Semelhanças e diferenças entre práticas discursivas não são naturais, quer dizer, não estão dadas a partir das especificidades dessas práticas, mas são construções culturalmente sujeitas a regras, normas e convenções específicas contingenciais. A própria separação entre ficção e história é uma dessas convenções. A teórica literária Linda Hutcheon coloca claramente a questão:

O que a escrita pós-moderna da história e da literatura nos ensinou é que a ficção e a história são discursos, que ambas constituem sistemas de significação pelos quais damos sentido ao passado [...]. Em outras palavras, o sentido e a forma não estão nos acontecimentos, mas nos sistemas que transformam esses "acontecimentos" passados em "fatos" históricos presentes. Isso não é um "desonesto refúgio para escapar à verdade", mas um reconhecimento da função de produção de sentido dos construtos humanos. (HUTCHEON, 1991, p. 122) 
Tais reflexões denotam uma nova relação do historiador com o seu objeto, ou mesmo uma nova atitude perante o saber historiográfico. Sem dúvida, elas deixam ainda mais complicadas as coisas para o historiador. Mas um dos objetivos da história e da teoria da história não é justamente complicar o que parece simples?

\section{3.}

A problematização teórica da narrativa repercutiu no plano epistemológico e contribuiu para a crise de paradigmas, modelos explicativos e teleologias da história. A maioria dos historiadores afirma que é importante, epistemológica e politicamente, manter a distinção entre ficção e não ficção, mesmo reconhecendo a justeza pós-moderna de afirmar que essa distinção não é tão clara quanto parece. A busca historiográfica de novas formas de narrativa passa necessariamente pela restauração da subjetividade do narrador: o escritor da história não pode mais esconder-se atrás das cortinas pretensamente objetivas dos "fatos" ou da linguagem falsamente impessoal da ciência. Mas a crise epistemológica trazida pelo pós-modernismo, pelo pós-estruturalismo e pela hermenêutica não abalou os alicerces da história a ponto de fazê-la desmoronar como um velho castelo em ruínas. Afinal, nunca se escreveu tanta história como nas últimas décadas. Para comprovar, basta folhear os catálogos das editoras, acessar os bancos de teses e percorrer livrarias, sebos e bibliotecas universitárias. Verifica-se, contudo, mudanças significativas. Tinha-se como dado e certo que o papel do historiador era explicar o mais cientificamente possível a realidade do passado como "coisa em si", material e concreta, como a um ente substantivo exterior ao discurso e à linguagem; as teses "narrativistas" afirmam que esse "fora" não existe: o passado "existe" na linguagem, no discurso, no texto. Haveria, desde então, dois caminhos: um explicativo (do passado como ente realmente subsistente, dado a priori); e um caminho mais interpretativo e construtivo: não existe um real ou um passado pronto e acabado, de que o discurso poderia ser um duplo ou uma "colagem" transparente, a ponto de converterse em uma representação verdadeira dos mesmos. Grosso modo, constata-se uma afirmação das teses "narrativistas" pari passu ao enfraquecimento do ideal objetivista, realista e verista da historiografia moderna. A narrativa historiográfica contemporânea, salvo exceções, não se autorrepresenta como cópia, reflexo ou imitação do real passado, mas como invenção e (re) criação imaginativa dele, sem pressupor a existência concreta do referente. As evidências são várias: a expansão do campo da história da historiografia; o retorno do gênero ensaístico e biográfico; a incorporação de elementos autoparódicos no discurso historiográfico; a explicitação da subjetividade narrativa; a problematização das escolhas teóricas; o ecletismo metodológico; a enunciação dos limites e possibilidades das fontes, entre outras manobras retóricas que assinalam, para o leitor, o lugar, o perspectivismo e mesmo o relativismo do discurso. Inclusive a micro-história, avessa à designação de pós- 
moderna, incorporou esses elementos e abriu-se à experimentação literária. Em ensaio recente, Carlo Ginzburg escreve:

\begin{abstract}
Antes de começar a escrever $O$ queijo e os vermes ruminei muito tempo sobre as relações entre hipóteses de pesquisa e estratégias narrativas [...]. Eu me propusera reconstruir o mundo intelectual, moral e fantástico do moleiro Menocchio por meio da documentação produzida por aqueles que o tinham mandado para a fogueira. Esse projeto [...] podia traduzir-se num relato capaz de transformar as lacunas da documentação numa superfície uniforme. Podia, mas evidentemente não devia: por motivos que eram ao mesmo tempo de ordem cognitiva, ética e estética. Os obstáculos postos à pesquisa eram elementos constitutivos da documentação, logo deviam tornar-se parte do relato; assim como as hesitações e os silêncios do protagonista diante das perguntas dos seus perseguidores - ou das minhas. Desse modo, as hipóteses, as dúvidas, as incertezas tornavam-se parte da narração; a busca da verdade tornava-se parte da exposição da verdade obtida (e necessariamente incompleta). $\mathrm{O}$ resultado ainda podia ser definido como "história narrativa"? Para um leitor que tivesse um mínimo de familiaridade com os romances do século $\mathrm{XX}$ a resposta era óbvia. (GINZBURG, 2007, p. 265).
\end{abstract}

Natalie Zemon Davis reconhece que a obra oferecida pelo historiador ao leitor é, em grande parte, uma invenção, mas "uma invenção construída pela atenta escuta das vozes do passado." (DAVIS, 1987, p. 21) Ficção, como a entende Davis, é "aquilo que é trabalhado, construído ou criado a partir do que existe." (PESAVENTO, 2008, p. 53) Ou do que um dia existiu.

A análise narratológica do discurso historiográfico redefiniu as relações entre sujeito cognoscente e objeto do conhecimento. Para os historiadores até o dia de ontem, o problema da subjetividade do escritor não passava de uma pedra no meio do caminho, obstáculo a superar rumo a uma história cada vez mais científica. Na contemporaneidade, o subjetivismo do historiador emerge com força redobrada. As teses "narrativistas", ao evidenciarem a presença do autor em seu discurso, e, ao mesmo tempo, situarem esse autor na cultura histórica de seu tempo e espaço, minou a ideia de uma objetividade plena; a isso os historiadores, recorrendo à teoria e à filosofia da ciência, responderam com a noção de objetivação: o controle possível do bias, da subjetividade do historiador na construção de seu próprio discurso. Há no mesmo processo uma revalorização da empiria, do arquivo, das fontes, embora o empirismo não sirva de álibi desde a crítica neokantiana de Cassirer à historiografia moderna.

[...] ainda que não possamos negar que toda grande obra histórica contém e supõe um elemento artístico, nem por isso se torna uma obra de ficção. Em busca da verdade, o historiador está sujeito às mesmas regras severas que sujeitam o cientista. Precisa utilizar todos os métodos da investigação empírica, reunir todas as provas disponíveis e cotejar e criticar todas as fontes. [...] Entretanto, o ato derradeiro e 
decisivo é sempre um ato da imaginação produtiva. (CASSIRER, 1997, p. 319).

Retoma-se, assim, a ideia de real não mais como referente do discurso, mas como signo do extinto. Trata-se, é claro, de um realismo mitigado, e não mais daquela "pobre ideia de real" de que falou Michel Foucault em sua crítica da história social. ${ }^{6} \mathrm{O}$ real não é mais a "coisa em si" - o passado - mas os indícios, as sobras, os restos significantes do real, e que não remetem a uma totalidade transparente e dada a priori. Nessa proposição, o real, desde o primeiro momento, aparece ao historiador como um real narrativizado. As fontes, ou melhor, os resquícios, indícios e toda a gama de documentos trazem já em si elementos narrativos. E não seria o célebre "paradigma indiciário", proposto por Ginzburg (1990), um modo de operar esta narrativização do passado ao tomar a fiç̧ão como paralela ao trabalho detetivesco (metódico) do historiador? Nesse sentido, a busca das pistas, sinais e indícios não seria mais que um modo de narrativizar o passado antes mesmo de compor textualmente uma narrativa histórica.

Em $O$ estilo na história, Peter Gay, muito sintomaticamente, reavaliou que "na profissão histórica moderna em geral a arte e a ciência não se separam nitidamente"; pelo contrário, "convivem com uma longa fronteira cheia de meandros, que é atravessada pelo trânsito erudito e literário sem grandes impedimentos e muitas formalidades.” (GAY, 1990, p. 167) Apesar de Gay não problematizar o caráter produtivo da linguagem e prender-se a um conceito de estilo como forma ornamental, trata-se de uma mutação significativa, um sinal dos novos tempos historiográficos. Para Georges Duby a história é uma imaginação documentada, um discurso que parte da explicitação do elemento subjetivo na elaboração do discurso:

\begin{abstract}
Na verdade, estou convencido da inevitável subjetividade do discurso histórico; pelo menos, do meu, estou inteiramente convencido. Isso não quer dizer que não faça tudo o que posso para estar o mais perto possível daquilo a que se pode chamar "a realidade", relativamente a essa imaginária construção mental que é o nosso discurso. (DUBY; LARDREAU, 1989, p. 41).
\end{abstract}

Em suma, mesmo a historiografia que recusa a pecha de pós-moderna indica, na prática como na teoria, a presença cada vez mais manifesta do primado linguístico e narrativista da história. Por mais que teoricamente sustentem a história como reduto da verdade alcançada

\footnotetext{
6 “Hay que desmitificar la instancia global de lo real como totalidad por restituir. No existe 'lo' real al que se podría acceder siempre y cuando se hablara de todo o de ciertas cosas más 'reales' que las demás, y que se nos escaparían, en aras de abstracciones inconsistentes, si nos limitamos a hacer aparecer otros elementos y otras relaciones. También habría que interrogar tal vez el principio, con frecuencia implícitamente admitido, de que la única realidad a la que debiera pretender la historia es la propia sociedad. Un tipo de racionalidad, una manera de pensar, un programa, una técnica, un conjunto de esfuerzos racionales y coordinados, unos objetivos definidos y continuados, unos instrumentos para alcanzarlos, etc., todo eso es lo real, aunque no pretenda ser 'la realidad' misma ni toda 'la' sociedad." (FOUCAULT, 1982, p. 46, grifo do autor).
} 
pelo bom método, flertam pudicamente com a literatura. Três exemplos justamente célebres dessa mistura são $O$ Queijo e os Vermes, de Ginzburg; O Retorno de Martin Guerre, de Natalie Zemon Davis; e Montaillou, de Emmanuel Le Roy Ladurie, já tornados clássicos.

4.

Por vezes observa-se, entre os historiadores, certa resistência a pensar o discurso histórico como linguagem, escritura e narrativa. É como se traíssemos a história, dando munição aos seus "inimigos" filosóficos e literários. Os historiadores, claro, pesquisam a linguagem das classes sociais, das comunidades e grupos, dos gêneros, dos marginais, etc. Mas raramente refletem sobre a linguagem que utilizam em suas próprias práticas e representações, sem as quais o passado é ininteligível. Essa recusa é ela própria um efeito historicamente constituído da disciplinarização e canonização da história. Quanto ao texto, os historiadores são tradicionalmente avessos a experimentações formais e narrativas. Os críticos desse conservadorismo, como Hayden White e Dominique LaCapra, apontam a semelhança entre o texto-padrão historiográfico e a narrativa romanesca do século XIX, como a sugerir que os historiadores não acompanharam as inovações literárias do século XX. Escreve White: “Toda disciplina é constituída por um conjunto de restrições ao pensamento e à imaginação, e nenhuma é mais tolhida por tabus do que a historiografia profissional." (apud KRAMER, 1992, p. 136) De fato, a partir da "formatação" da história em uma disciplina, aqueles hábitos a que a romancista Marguerite Yourcenar chamou "os defeitos típicos da dissertação acadêmica puramente rotineira" começou a ditar o modo de produção do texto histórico. (YOUCENAR, 1982, p. 328) Apenas muito recentemente, com a crise dos grandes modelos explicativos, os historiadores perceberam que o regime disciplinar separou forma e conteúdo do texto, subordinando a primeira ao segundo; ou então, mais simplesmente, que a historiografia moderna desconsiderou os problemas "estéticos" da narrativa e o papel da retórica na produção da "verdade" do passado.

Desde Michel de Certeau e sua concepção de operação historiográfica, sabemos que a história se faz em relação com um lugar social, práticas de pesquisa, procedimentos de análise e uma escrita; tais reflexões foram possíveis a partir dos anos 1970, marcados por um "despertar epistemológico". (CERTEAU, 2000, p. 66) Essa operação historiográfica, contudo, resultaria em uma terceira etapa, a da ausência do sujeito no discurso: o historiador, ao escrever a história, apagaria o seu lugar social, as práticas metodológicas e a escritura, encenando assim um discurso sem autor. (CERTEAU, 2000, p. 66) Barthes foi ainda mais incisivo: 
Trata-se do caso em que o enunciador entende "ausentar-se" do seu discurso e em que há, consequentemente, carência sistemática de qualquer signo que remeta ao emissor da mensagem histórica: a história parece contar-se sozinha. Esse acidente tem uma carreira considerável, pois que corresponde de fato ao discurso histórico dito "objetivo" (em que o historiador jamais intervém). Na realidade, nesse caso, o enunciador anula a sua pessoa passional, mas a substitui por outra pessoa, a pessoa "objetiva": o sujeito subsiste em sua plenitude, mas como sujeito objetivo; é o que Fustel de Coulanges chamava significativamente (e com bastante singeleza) de "castidade da História". (BARTHES, 2004b, p. 169).

Tal forma de apresentar o discurso corrobora a matriz disciplinar moderna da história como ciência. Mas a contestação do dualismo sujeito-objeto retira da história o ideal de reconstruir a "verdade" daquilo que de fato ocorrera: "a história 'objetiva' [...] perpetuava com essa ideia de uma 'verdade' um modelo tirado da filosofia de ontem ou da teologia de anteontem; contentava-se com traduzi-la em termos de fatos históricos". (CERTEAU, 2000, p. 67). A evidência do caráter operatório da história trouxe para o centro da teoria o autor - ou a subjetividade -, uma vez que o seu apagamento no espaço textual revelou-se constitutivo do saber:

$O$ retorno às decisões pessoais se efetuava baseado em dois postulados. Por um lado, isolando um elemento filosófico do texto historiográfico supunha-se uma autonomia para a ideologia: era a condição de sua extração. Uma ordem das ideias era posta à parte da prática histórica. Por outro lado (mas as duas operações caminham juntas), sublinhando as divergências entre os "filósofos", descobertos sob suas vestes de historiadores, referindo-se ao insondável de suas ricas instituições, fazia-se destes pensadores um grupo isolável de sua sociedade, a pretexto de sua relação direta com o pensamento. $O$ recurso às opções pessoais provocava curto-circuito no papel exercido, sobre as ideias, pelas localizações sociais. O plural destas subjetividades filosóficas tinha, desde então, como efeito discreto, conservar uma posição singular para os intelectuais. Sendo as questões de sentido tratadas entre eles, a explicação de suas diferenças de pensamento equivalia a gratificar o grupo inteiro com uma relação privilegiada com as ideias. Nada dos ruídos de uma fabricação, de técnicas, de imposições sociais, de posições profissionais ou políticas perturbava a paz desta relação: um silêncio era postulado desta epistemologia. (CERTEAU, 2000, p. 68).

Pretender que o historiador se assuma como narrador da própria história narrada choca-se, de uma forma ou de outra, com toda uma tradição historiográfica disciplinar. Outras questões derivadas - a "consciência histórica", o "sentido da história", a "função social" do conhecimento histórico, o papel dos historiadores como intelectuais e a intervenção direta nos domínios públicos - também assumem uma nova dimensão. Reconhecer que o sujeito do conhecimento é o narrador presente em seu texto implica conceber o passado para além do próprio passado, e não mais assumir o papel de voz silenciosa e autoritária mediante a qual o passado fala de si e por si mesmo. 
Como afirma André Burguière, "A história é e será sempre um trabalho de escrita." (BURGUIÈRE, 1993, p. 9) Aceitar essa proposição evitaria muitos falsos problemas nos campos da teoria e da epistemologia da história. Os historiadores que há várias décadas engendram fórmulas criativas para construírem seus objetos nada tem a temer com esses ventos retóricos e poéticos. Nada impede a história de continuar reclamando seu pobre quinhão nos domínios da ciência; nada impede que ela um dia possa vir a ostentar o sóbrio status de ciência, com todos os comprometimentos políticos inseparáveis de qualquer tirania do logos. Por outro lado, não há nenhuma garantia de que a história possa vir a se tornar uma arte digna desse nome. A literatura é, para o historiador, não um porto seguro (que simplesmente não existe), mas outro ideal, linha de fuga ou artimanha da libido, ilusão projetada pelo desejo.

\section{Bibliografia}

AMHERDT, F. X. Apresentação. In: RICOEUR, P. A hermenêutica bíblica. Tradução de Paulo Menezes. São Paulo: Loyola, 2006.

BARTHES, R. A morte do autor. In:-------.. O rumor da língua. Tradução de Mário Laranjeira. São Paulo: Martins Fontes, 2004a. p. 57-64.

. Introdução à análise estrutural da narrativa. In: BARTHES, R. et al. Análise estrutural da narrativa: pesquisas semiológicas. Petrópolis: Vozes, 1976.

O discurso da história. In: O rumor da língua. Tradução de Mário Laranjeira. São Paulo: Martins Fontes, 2004b. p. 163-180.

BURGUIÈRE, A. Prefácio. In: . Dicionário das ciências históricas. Tradução de Henrique de Araujo Mesquita. Rio de Janeiro: Imago, 1993.

CASSIRER, E. Antropologia filosófica. Tradução de Vicente Felix de Queiroz. 2. ed. São Paulo: Mestre Jou, 1997.

CERTEAU, M. A operação historiográfica. In: A escrita da história. Rio de Janeiro: Forense Universitária, 2000.

DAVIS, N. Z. O retorno de Martin Guerre. Tradução de Denise Bottmann. Rio de Janeiro: Paz e Terra, 1987.

DUBY, G.; LARDREAU, G. Diálogos sobre a nova história. Lisboa: Dom Quixote, 1989. FEBVRE, L. Viver a história. In:----------. Combates pela história. Lisboa: Editorial Presença, 1977. p. 20-48.

FOUCAULT, M. El povo y la nube. In: La imposible prisión: debate con Michel Foucault. Barcelona: Editorial Anagrama, 1982. 
GAY, Peter. O estilo na história. Tradução de Denise Bottmann. São Paulo: Companhia das Letras, 1990.

GINZBURG, C. Micro-história: duas ou três coisas que sei a respeito. In:----------. O fio e os rastros: verdadeiro, falso, fictício. São Paulo: Companhia das Letras, 2007.

Sinais, raízes de um paradigma indiciário. In: Mitos, emblemas e sinais. São Paulo: Companhia das Letras, 1990.

GOULEMOT, J. M. Romance e história. In: BURGUIÈRE, A. (Org.). Dicionário das ciências históricas. Tradução de Henrique de Araujo Mesquita. Rio de Janeiro: Imago, 1993.

HUTCHEON, L. Poética do pós-modernismo: história, teoria, ficção. Tradução de Ricardo Cruz. Rio de Janeiro: Imago, 1991.

JENKINS, K. A história repensada. São Paulo: Contexto, 2001.

KOTHE, F. R. Para ler Benjamin. Rio de Janeiro: Francisco Alves, 1976.

KRAMER, L. S. Literatura, crítica e imaginação histórica: o desafio literário de Hayden White e Dominique LaCapra. In: HUNT, L. (Org.). A nova história cultural. Tradução de Jefferson Luiz Camargo. São Paulo: Martins Fontes, 1992.

MARTINS, M. F. A ficção da história, Jornal de Letras, Lisboa, 23 jun. 1992.

MIGNOLO, W. Lógica das diferenças e política das semelhanças: da literatura que parece história ou antropologia, e vice-versa. In: CHIAPPINI, L.; AGUIAR, F. W. (Org.). Literatura e história na América Latina. São Paulo: EDUSP, 1993. p. 122-133.

NUNES, B. Narrativa histórica e narrativa ficcional. In: RIEDEL, D. C. (Org.). Narrativa: ficção e história. Rio de Janeiro: Imago, 1988. p. 9-35.

PESAVENTO, S. J. História \& história cultural. 2. ed. Belo Horizonte: Autêntica, 2008.

RICOUER, Paul. A metáfora viva. Tradução de Dion Davi Macedo. São Paulo: Loyola, 2000.

Hermenêutica e mundo. In: Escritos e conferências 2: hermenêutica.

Tradução de Lúcia Pereira de Souza. São Paulo: Edições Loyola, 2011.

A memória, a história, o esquecimento. Campinas: Editora da Unicamp, 2007.

SANTOS, J. F. "Barth, Pynchon e outras absurdetes: o pós-modernismo na ficção americana". In: OLIVEIRA, R. C. et al. Pós-modernidade. 5. ed. Campinas: UNICAMP, 1995.

TOYNBEE, A. J. A study of history. Oxford: Oxford University Press, 1972.

VATTIMO, G. Ciências humanas e sociedade da comunicação. In: ---------.. A sociedade transparente. Lisboa: Edições 70, 1991.

WHITE, H. A questão da narrativa na teoria histórica contemporânea. In; NOVAIS, F. A.; 
SILVIA, R. F. (Org.). Nova história em perspectiva. São Paulo: Cosac Naify, 2011.

El contenido de la forma. Buenos Aires: Paidos, 1992.

Meta-história: a imaginação histórica do século XIX. São Paulo: Editora da Universidade de São Paulo, 1995.

O texto histórico como artefato literário. In: Trópicos do discurso: ensaios sobre a crítica da cultura. São Paulo: EDUSP, 1994a. p. 97-116.

Teoria literária e escrita da história. Estudos Históricos, Rio de Janeiro, v. 7, n. 13, p. 21-48, 1994b.

YOUCENAR, M. Memórias de Adriano: seguido do caderno de notas das "Memórias de Adriano" e da nota. Tradução de Martha Calderaro. Rio de Janeiro: Nova Fronteira, 1982.

ZAJDSZNAJDER, L. A travessia do pós-moderno: nos tempos do vale-tudo. 2. ed. Rio de Janeiro: Gryphus, 1994. 